\title{
Combinatory Linguistics: An area of theoretical and applied language study
}

\section{Marina Vlavatskaya}

Dep. of Foreign Languages (Dep. of Humanities), Novosibirsk State Technical University (NSTU), Novosibirsk, Russia

\section{Email address:}

vlavatskaya@list.ru

\section{To cite this article:}

Marina Vlavatskaya. Combinatory Linguistics: An Area of Theoretical and Applied Language Study. International Journal of Language and Linguistics. Vol. 2, No. 3, 2014, pp. 165-173. doi: 10.11648/j.ijl1.20140203.15

\begin{abstract}
This paper aims to describe Combinatory Linguistics as an area dealing with syntagmatic relations of language units and their combinatory profile. In this respect collocability is a subject of separate study and it should be described in an independent branch of language area. Combinatory Linguistics includes theoretical (Combinatory Lexicology, Combinatory Semasiology) and an applied section (Combinatorial Lexicography). The perspectives, objectives, terminological framework and the fundamental theory prove the importance of combinatory science about language in the structure of theoretical and applied linguistics. Within the discipline the following aspects of studying combinability of language units can be singled out: methodological, metalinguistic, functional, semantic, cognitive, psycholinguistic, normative, etc.
\end{abstract}

Keywords: Combinatorics, Syntagmatics, Collocability, Combinability, Compatibility, Valence, Context, Collocation

\section{Introduction}

It is generally recognized that language as a system of signs contains collocability or the property of language units and phenomenon which is explicitly observable in speech and determines the most important parameters of functioning language as a tool of cognition and communication. The first thing to be noticed is that collocability is a subject of separate study and it should be described in an independent area of theoretical and applied study or Combinatory Linguistics. The syntagmatic aspect of language and speech is the subject of research in this area consisting of the elements filled with combinatory and syntagmatic properties which implement cognitive activity and speech communication of the person.

The purpose of the article is to give reasons to Combinatory Linguistics which is devoted to the study of syntagmatic relations of linguistic units and their combinatory profile. Combinatory Linguistics includes theoretical and applied sections. Its fundamentals and terminological base justify the importance of this language area in the structure of theoretical linguistics.

The relevance of this research is caused by the problems which are directly connected with:

1) the attitude of modern linguistics to the investigation of functional and speech aspects of the language;

2) communication without which it is impossible to imagine the existence of modern society;

3 ) the study of mechanisms of the word meaning development;

4) formation and interpretation of texts;

5) the need of modern linguistics to generalize and classify combinatory and syntagmatic properties of language units;

6) expansion of foreign language teaching;

7) the need of compiling combinatory in different spheres of language, etc.

In the course of this investigation the following methods and analyses have been used:

1) general (descriptive, contrastive, oppositional, induction and deduction, introspection and interpretation, classification and systematization);

2) special (valent, distributional, contextual, componential, functional, semantic, analyses of sememes and semes, the analysis of dictionary definitions of lexemes, etc);

The connotional syntagmatic analysis has been applied to expressive words. Its purpose is to identify connotational components in the lexical meanings of collocated words that restrict and prescribe collocability.

The significance and delimitation of Combinatory Linguistics is conditioned by the solution of theoretical study and description of combinatory abilities of language units as well as the need to systematize the material that has been saved up and will be created anew. Combinatory Linguistics covers an extensive area of linguistics. It can be 
argued that collocability is the base of speech communication as a whole. It testifies that borders of the area are not strictly limited and remain rather vague. Combinatory Linguistics correlates with such fields of knowledge as Psycholinguistics, Cognitive Linguistics, Pragmatics, the Theory of Communication, the Theory of Speech Acts, and the Theory of Coding and Decoding, etc. In a narrow sense Combinatory Linguistics includes syntagmatics and combinatorics

\section{Theoretical Framework}

\subsection{Methodological Bases}

The historical analysis of collocational doctrines in Russian and foreign linguistics confirms the importance of syntagmatic concept, i.e. the aspect of the language containing the rules of combinability of single-level units in language and speech. Interpretation of syntagmatic relations of words in 1960-1970-es occupied an important place in works on semantics, syntax and lexicology [1-6]. Although with a change of linguistic paradigm and turning to the anthropocentric approach to language study the problem of linear relations of words was practically ignored. The syntagmatic principle of speech was recognized as the most important in the implementation of cognitive and communicative functions of the language.

Another significant aspect laid in Combinatory Linguistics is combinability. It consists in studying word combinations subordinated to certain communicative tasks under existing conditions of their realization. The choice of the model of the utterance and filling it with certain lexical units depend on the speaker's intentions and the specific situation in which the speaker takes part. A wide study of combinability of language units from the historical viewpoint has revealed the theoretical and methodological fundamentals of Combinatory Linguistics. The theory of A. Diskol and early doctrines of Russian linguists [7-10] became the preconditions of its origin. However, the area of their interests was limited to syntax as a process of syntagmatic deployment in time since the formation of blocks on syntactic dependences is more available to observation.

The founder of Syntagmatics F. de Saussure considered it as compatibility based on the linear relations of language units [11]. The deliberate system of syntagma's principles became the result of the Syntagmatic Theory development: linearity (F. de Saussure), binary (Ch. Bally), interdependence of its constituent elements (F. Mikush) and the ability to integrate ( $\dot{\mathrm{E}}$. Benveniste).

It is necessary to note the contribution of Western Linguistics to the theoretical and methodological foundations of Combinatorial Linguistics which involves the first wave of French Syntagmatics [12], the German Theory of Valence [5], the Theory of Meaning and Context in London Linguistic School [13], Danish structuralism or Glossematics [14], Descriptive Linguistics [15], Semantic
Synthesis [6], etc.

The theoretical and methodological foundations of Combinatory Linguistics in the Russian tradition were laid down by the Theory of Valence [16], the Theory of Collocability [17], the Theory of General and English Syntagmatics [18], the Contextological Theory [19], Syntactic Sintagmatics [20], Lexical Sintagmatics [21], Semantic Sintagmatics [22], the Theory of General Phraseology [23], Composite Semantics [24], etc.

Thus, since the middle of the XXth century the theory of collocability has made significant achievements in the study of syntagmatic relations of words and their combinatory profile.

\subsection{Metalinguistic Aspect}

Combinatory Linguistics covers a wide range of problems and acts as an independent branch that has collocability as the subject of description. In this regard there is a problem of metalanguage by means of which its description is possible.

The facts show that numerous concepts of collocability in the XXth century have caused the emergence of synonymous terms that led to incoordination of terminological description of collocability.

The formation of combinatory termbase consists in making the system which includes some blocks built in the main sections of the discipline. At the head of the system there is syntagmatic concept comprising one of the main principles of communication or principle of speech linearity The speech aspect of collocability in all languages is based on this principle.

In the core of the terminological system there are terms that reflect compatibility of language units (syntagmatics, collocation, valence, distribution, context, etc.). Periphery is made by the terms which are indirectly related to this area, nevertheless, play an essential role in the description of properties and functions of collocability. Thus systematization of terms has allowed us to form the basic concepts of syntagmatics.

Firstly, it is valence or potential compatibility of language units or ability of their connection in speech laid down in the system of language; it relates to the level of language syntagmatics

Secondly, it is collocability or realization of the valance of words or real collocability which relates to the level of speech syntagmatics. Special importance in Combinatory Linguistics is gained by the concept 'position' or the condition for the existence of a language unit as a part of a complex unit, or its place in the language system.

Thirdly, the term base of the combinatory science includes the concepts relating to types and levels of syntagmatics, various types of valence, distribution and context, collocation and colligation as well as the terms designating lexical semantic and phraseological coherence of word meanings.

At the same time the terminological field of Combinatory Linguistics includes new terms: combinatory lexicology, 
combinatory semasiology, dictionary of combinatory type (descriptive, orthological, aspectual, polyaspectual, etc.), connotational syntagmatic analysis, syntagmatic macrocomponent of lexical meaning (selective microcomponent, prescriptive microcomponent, restrictive microcomponent), transformation of syntagmatic structures, etc.

Thus the presence of terminological system confirms the idea that this area is a separate branch of linguistics with its conceptual and terminological base which functions as a tool for describing phenomenon of collocability.

\subsection{Functional Semantic Aspect}

Of paramount value in Combinatory Linguistics is functional semantic aspect of studying collocability within various functions of collocations are investigated and interpreted. Collocability as the language phenomenon has a number of significant functions for communication including updated lexical meaning of the word, demarcation values of ambiguous words and homonyms, creation of occasional phrases, usage of expressive words and comic effect, etc.

The functional semantic aspect is quite complex as comprises other aspects of collocational study, for example, cognitive and psychological. The cognitive one is associated with the language consciousness and the idea of interrelation of language and thought. Nowadays an active study of the language consciousness has become an integral part of papers on the description of concepts and human speech [25-26]. The language consciousness forms, stores, and converts linguistic signs as well as the rules for their combinations and use. Different ideas about the world in different cultures and different interpretations of the same concepts in different languages affect collocability. Collocations are the result of the language consciousness of the native speaker that reflect the cognitive nature of speech production.

The psycholinguistic aspect of investigating collocability is connected with the study of how the language system and the rules for constructing speech allow people to express their thoughts [27-30]. The special importance is gained here by operations of selective structural elements of the utterance considered as universal operations of speech production. In that way syntagmatics organizes consistent implementation of thoughts in a speech utterance by means of semantically and structurally related words. Such language phenomenon as transformations of syntagmatic structures acquires special theoretical justification. They can be explained by the existence of syntactic structures in the language which contain paradigmatic elements. Complete understanding of such structures requires additional mental operations.

\subsection{Normative vs Non-normative Aspect}

The systematization of collocational material which is considered in the normative vs non-normative aspect has contributed to the classification of collocations in accordance with the principle 'standard - admissibility non-standard' [31]. The three types of collocations can be differentiated in the following way:

1) codified (recorded in authoritative lexicographic reference books [32-34]), for example,

rapid acceleration, slight accent, serious accident, general acclaim, poor accommodation, brilliant career, curious looks, tend to accumulate, stomach ache, personally acquainted, firm action, commit an act, etc.

2) usual (developed in the people's language tradition), for example,

dead line, hot line, black money, hot money, black market, Web-site, special offer, black-tie dinner, reality show, time bargain, financial leasing, on-line service, on-line mode, network marketing, etc.

3) occasional (author's) word-combinations (occasional metaphors), the formation of which is correlated with the author's individual vision of the world, for example,

flash crowd, roving newstaper (L. Niven), slyph-like maximegalacticans, Electronic Thumb (D. Adams), fog-threatening evening (J. Fowles), poltergeist-tossed trash, a pincer-like grip (J.K. Rowling), etc.

They are recognized as valid in terms of the language standard because they correspond to the phonetic, morphological, semantic, and other linguistic standards.

Speech mistakes such as

*absolutely important, *accurate date, *editing company, *rude mistake, *deep dream, *to visit a doctor, etc.)

caused by ignorance of the rules of collocability and syntax and belong to non-standard word combinations.

Table 1. Types of Collocations according to the principle 'standardadmissibility - non-standard'

\begin{tabular}{lll}
\hline \multicolumn{1}{c}{ Principle } & \multicolumn{1}{c}{$\begin{array}{c}\text { Type of } \\
\text { collocation }\end{array}$} & \multicolumn{1}{c}{ Example } \\
\hline 1. 'standard' & a) codified & $\begin{array}{l}\text { slight accent, } \\
\text { serious accident, } \\
\text { black money, } \\
\text { hot money } \\
\text { a pincer-like grip, } \\
\text { roving newstaper } \\
\text { 2. 'admissibility' }\end{array}$ \\
b) usual & occasional & $\begin{array}{l}\text { *accurate date, *diting } \\
\text { company }\end{array}$ \\
\hline
\end{tabular}

It should be noted that the process of continuous language development affects the process of redistribution of relationship between words which causes may be both linguistic and extralinguistic. The research shows that the collocational standard cannot have strict and rigid character. Therefore, the classification of collocations according to the principle 'standard - admissibility - non-standard' is open for their replenishment and redistribution.

Obviously, collocability is the most dynamic element of the language structure. There are significant changes as it develops by the language usage showing features of variability and unpredictability [35].

All facts above prove the presence of methodological, metalinguistic, functional semantic, cognitive, psycholinguistic, normative, aspects, etc. of studying collocability. 


\section{Combinatory Lexicology}

With regard to the purpose of the study Combinatory Linguistics can be subdivided into some appropriate sections.

The existence of combinatory potential in semantics of the word and its ability to various types of systematization testifies the theoretical importance of this language phenomenon and represents the basis for selection of Combinatory Lexicology which describes combinability of lexical units [32-34, 36]. It consists of two subsections (Combinatory Semasiology and Combinatory Lexicography) and has conceptual and terminological base which forms its terminological system and interprets combinatory and syntagmatic properties of lexical units.

\subsection{Combinatory Semasiology}

In this section we turn to Combinatory Semasiology which studies inseparable connection of collocability and semantics [31]. The meaning or sense of the word is realized only together with another word (a collocate) that clarifies or concretizes the first one, for example,

hard (unhappy) life, hard (sharp) words, hard (severe) frost, hard (strong) evidence, hard (of resentment) feelings, hard (metallic) money, hard (stringent) conditions, hard (rigorous) discipline, hard (heavy) blow, etc.

The condition of clarification and specification of the lexeme meaning is both linguistic and extralinguistic context (the context of the situation). Combinatory Semasiology solves the problems of the relations between semantics and collocability as well as the identification of collocational mechanisms in the structure of the lexical meaning of the word and in addition to that all sorts of restrictions on collocability, etc.

Semantics of lexical units is filled with combinatory potential that is confirmed by the fact of finding out a special syntagmatic macrocomponent in the lexical meaning, or the collocational mechanism which permits to implement collocability to speech. It consists of three microcomponents which have specific functions [31].

1. The selective microcomponent determines combinatory potential of the word. For example, the adjective dirty in the meaning 'not clean' is used in a wide range of collocations:

water, snow, lake, river, park, street, flat, room, floor, bath, canteen, linen, clothes, dress, shirt, collar, glass, plate, spoon, face, hands, body, etc.

2. The prescriptive microcomponent prescribes obligatory collocability. For example, adjective malic is collocated only with the noun acid; dundreary only with whiskeys; auburn only with hear, etc.

3 . The restrictive microcomponent confines collocability or implements further specification within a semantic class of lexemes. For example,

adjective disappointed «dissatisfied with someone or something» is collocated with a lot of adverbs of semantic class «a great degree of character»: bitterly, considerably, crushingly, completely, deeply, desperately, dreadfully, extremely, grossly, hugely, massively, profoundly, strongly, terribly, tremendously, etc., but it is not collocated with adverbs *totally or *appallingly.

Table 2. The structure of the sintagmatic macrocomponent in the lexical meaning.

\begin{tabular}{ll}
\hline \multicolumn{2}{l}{ Sintagmatic Macrocomponent } \\
\hline Type / microcomponent & Functions \\
\hline 1. Selective microcomponent & $\begin{array}{l}\text { determines combinatory potential of } \\
\text { the word }\end{array}$ \\
2. Prescriptive & prescribes obligatory collocability \\
microcomponent & restricts collocability or implements \\
3. Restrictive & further specification within a semantic \\
microcomponent & class of lexemes \\
\hline
\end{tabular}

Let us now turn to the connotational syntagmatic analysis which is applied to identify the coinciding components of connotation in collocations. It helps to find out combinatory prescriptions and restrictions in the connotational (expressive and evaluative) collocations, for example,

luck (good, better, pure, sheer, bad, ill, rotten, tough, etc.).

Luck is 'an influence that seems to make things especially good things, happen to people for no particular reason'. Further it is necessary to divide it into the components of connotation.

a) stylistic component - neutral;

b) emotional component - positive or negative;

c) evaluative component - approving or disapproving;

d) expressive component - neutral;

e) intensive component - neutral.

As we can see the noun luck without a collocate (a word that is habitually juxtaposed with another one with a frequency greater than chance) denotes 'success'. However, if it depends on its collocate it can get either positive or negative connotations, for example good luck or bad luck.

The theoretical provisions that Combinatory Lexicology has developed help to solve the problem of demarcation of semantic, lexical and phraseological collocability. The factor of their distinction is different types of sememes in the structure of collocation. Sememes are designated by the lexemes comprising the phrase and identified by means of sememe analysis [23]. Collocations having in their structure denotational sememes correlated with the real world (D1+D1) are formed on the basis of juxtaposition of meanings and enter the area of semantic collocability, for example,

right hand, high building, dry grass, university education, stormy sea, thin layer, bake a pie, etc.

The phrases which are formed by means of combination containing two denotational sememes (D1+D2 (figurative meaning) and D2+D2) are included in the area of lexical collocability, for example,

head of the school, high prices, dry weather, to hire hands, thin soup, university years, dry weather, etc.

The phrases comprising at least one of connotational sememes (K1, K2 or K3 (idiomatic meaning of different degrees)) enter the area of phraseological collocability, for example,

to draw attention, to start a family, blind alley, birds of feather, 
spick and span, to make friends, to start a family, to take a walk, to take a step, to take a run, to take a jump, to take a look, to take a dive, to take a nap, etc.

Table 3. The demarcation of semantic, lexical and phraseological collocability.

\begin{tabular}{|c|c|c|c|}
\hline \multicolumn{2}{|c|}{ Free phrases } & \multirow{2}{*}{\multicolumn{2}{|c|}{$\begin{array}{c}\text { Bound phrases } \\
\text { Phraseological } \\
\text { collocability }\end{array}$}} \\
\hline Semantic collocability & Lexical collocability & & \\
\hline \multirow[t]{6}{*}{ D1D1 } & D1D2 D2D2 & D1K1 & $\mathrm{D} 2 \mathrm{~K} 1$ \\
\hline & & D1K1 & $\mathrm{D} 1 \mathrm{~K} 2$ \\
\hline & & $\mathrm{D} 2 \mathrm{~K} 2$ & D1K3 \\
\hline & & $\mathrm{D} 2 \mathrm{~K} 3$ & К1К2 \\
\hline & & К2К2 & К1К3 \\
\hline & & К 2 К 3 & К $3 К 3$ \\
\hline
\end{tabular}

It must therefore be concluded that Combinatory Lexicology is developing provisions which allow us to demarcate various types of collocability due to the sememe analyses of the words going together.

\subsection{Other Combinatory Classifications}

In this section let us move onto the problem of collocability that can be classified according to different criteria.

The first classification concerns the differentiation of collocations by the quantity of collocated words with the main word and finds out the following types [23]:

1) free collocability (having the largest number of collocations), for example,

destroy can 'ruin a lot of material and non-material things': country, town, building, army, enemy, plans, dreams, hopes, etc.

2) wide collocability (expressed in the ability of a lexeme to be combined with lexemes of several lexical semantic groups (LSG) and realize different sememes (denotational and connotional), for example,

adjective great can be used in sememes of D1 and D2 status in the following meanings: 1) about something that is bigger and more than usual: a great hole, great masses of population, great difficulty (danger, opportunity, advantage, patience, pleasure, etc.); 1a) very large and impressive: the great river (feast, etc.); 2) about well known or outstanding people: great woman (poet, artist, writer, scientist, sportsman, etc.); 3) about something that is important and powerful: great power (state); 4) about important events or situations: great occasion (disaster, war, etc.); 5) long and prolong: great while (age, etc.); 6) informal enthusiastic about something or somebody: great admirer (fan, talker, walker, reader, etc.); 7) informal something that is very good, enjoyable, attractive: great day (place, time, party), etc.

3) group collocability (characterized by the ability of a lexeme to be combined with a number of lexemes belonging to one or two LSG), for example,

to sew: 1. to make or repair clothes using a needle and thread (clothes): sew a shirt, skirt, blouse, dress, suit, trousers, coat и т.д.; 2. to fasten something using a needle and thread (on clothes): sew a button, pocket, bow, ribbon, etc.
4) single collocability (expressed in the ability of a monosemantic word or lexical semantic variants (LSV) of the polysemantic word to be combined only with a certain quantity of semantically collocated words), for example, hazel eyes, addle eggs, artesian well / spring, bissextile year, consuetudinary law, kitcat size, to divulge a secret etc.

5) serial collocability (characterized by steady collocability of several series of lexemes with variations of lexemes inside these series), for example,

effectively build, successfully create, creatively build, effectively work, successfully build, etc.

Table 4. Classification of collocability according to the quantity of collocated words.

\begin{tabular}{ll}
\hline \multicolumn{1}{c}{ Types of collocability } & \multicolumn{1}{c}{ Characteristics } \\
\hline 1. Free collocability & $\begin{array}{l}\text { the largest number of collocations } \\
\text { the ability of a lexeme to be combined with } \\
\text { lexemes of several lexico-semantic groups } \\
\text { the ability of a lexeme to be combined with a } \\
\text { number of the lexemes belonging to one or two } \\
\text { lexico-semantic groups } \\
\text { the ability of the monosemantic word or } \\
\text { lexico-semantic variants of the polysemantic } \\
\text { word to be combined only with a certain }\end{array}$ \\
5. Single collocability & $\begin{array}{l}\text { quantity of semantically collocated words } \\
\text { steady collocability of several series of lexemes } \\
\text { with variations of lexemes inside these series }\end{array}$ \\
\hline
\end{tabular}

According to this principle lexemes depending on their meanings are characterized by a certain type of collocability and can possess both narrow and wide collocational range.

The next classification regards with the differentiation of collocability by the nature of communication between components and causes the following separation:

1) contact collocability when words correlated to the sense are located at the minimum distance from each other, for example,

We will work with the legal profession to open up new opportunities to women and to black and ethnic minority groups, and create an independent judicial appointments commission (It's time to get Britain working again. London: The Labour Party, 1992, BNC): legal profession, new opportunities, ethnic minority groups, black minority groups, judicial commission, to open up opportunities, opportunities to women, appointments commission;

2) discrete collocability when words correlated to the sense are located within some distance as in the sentence:

Bitterness she could understand, reluctance, anger (William Deeping)

It is important to emphasize that discrete collocability is caused by inversion as the peculiarity of the English language is the fixed word order. The position of the word bitterness is obviously disordered;

3) distant collocability when words correlated to the sense appear only in consciousness of the person. For example,

$$
\text { - Waiter! }
$$




\author{
- Yes, sir. \\ - What's this? \\ - It's bean soup, sir. \\ - Never mind what it has been. I want to know what it is now.
}

In this context the words bean и been are homophones. The use of homophones in this situation creates a comic effect. The visitor of restaurant understands collocation bean soup as it has been soup. This example shows that collocations can be incorrectly interpreted by participants of the real situation.

Table 5. Classification of collocability according to the nature of communication between components

\begin{tabular}{ll}
\hline Types of collocability & \multicolumn{1}{c}{ Characteristics } \\
\hline 1.Contact collocability & $\begin{array}{l}\text { words correlated with the sense are located at } \\
\text { the minimum distance from each other } \\
\text { words correlated with the sense are located at }\end{array}$ \\
2. Descrete collocability some distance from each other usually within a \\
few sentences or a text \\
3. Distant collocability
\end{tabular}

As has been seen the word needs to be defined or clarified and this function is assumed by the other word or words. They can be in close proximity or great distance. Sometimes the defined word verbalizes only in the person's conciousness if it is caused by the conditions of extralinguistic situation.

\section{Combinatory Lexicography}

We can now go to the applied section of the combinatory science or Combinatory Lexicography that develops lexicographical principles and methods of compiling dictionaries which interpret collocability [31]. It is inseparable from Combinatory Lexicology as it has collocability as a subject of description and belongs to the area of Combinatory Linguistics as a whole. The purpose of Combinatory Lexicography is to improve theoretical and practical development of combinatory dictionaries and adequate collocational interpretation of words in them.

Let us introduce the definition of a combinatory dictionary which denotes a lexicographic reference book whose objective is the description of certain types of collocations by means of syntactic models and/or collocates grouped together according to the semantic characteristics and illustrated by contextual examples.

The theoretical provisions of Combinatory Lexicography are justified by presentation, firstly, of the parameters of combinatory dictionaries and, secondly, of their classification which has been worked out on the following bases:

1) the aim (linguocentric vs anthropocentric) and the purpose of the dictionary (system, collocations, learner's);

2) the value of collocability (aspectual vs polyaspectual dictionaries);

3) the description of the type (syntactic, lexical, lexical and syntactic) of combinability;
4) the principle of collocational description (syntactic, semantic, functional);

5) the functional orientation (general-purpose, idiomatic, language for specific purpose)

6) the character of collocational description (standard vs descriptive dictionaries);

7) the character of the word arrangement (semasiological vs onomasiological dictionaries);

8) ways of representation of the word meaning (monolingual, bilingual, bilingualized, polyglot dictionaries);

9) methods / ways of collocational description (lexical sets, phrases and sentences, formulas, chunks of words, enumerative representation, lexical functions, etc.).

The most acceptable interpretation of collocability in the combinatory dictionary is possible only within Combinatory Lexicography as scientifically reasonable section of Combinatory Linguistics.

According to the principles developed in Combinatory Lexicography the model of English-Russian combinatory dictionary for learners has been worked out.

The special approach to the treatment of the word in the model 'Sense $\Leftrightarrow$ Text' is justified by the proposition 'the use of lexical functions is the convergence of individual phraseology in the language to simple concepts which are universal for all languages' [21]. On this basis a dictionary is a tool for performance of the essential task. In other words its function must reflect all information necessary for production and perception of any utterances of this language.

This study has shown us the reliable results which have been used in developing a model of English-Russian combinatory dictionary for learners which represents a lexicographical reference book based on the concept designed on linguistic, lexicographical and methodological principles of the treatment of headwords.

One of the entries from the mentioned dictionary is presented below.

Hope $v$ want and expect something to happen надеяться $\mathrm{Adv}+\mathrm{N}$

Mang: very much: dearly, desperately, earnestly, fervently, really, sincerely very much I earnestly hope that the United States and Canada shall become allies. I hope dearly that history doesn't repeat. I early hope hat the ending will be filled with surprises, none of which I wish to predict $\sim$ горячо, искренне, очень

Ver: definitely: certainly, truly We certainly hope that you will enjoy reading the book. We truly hope that peace will come to Bahrain soon твёрдо

АнтиVer: in vain: in vain, vainly We wait in vain because we hope in vain. Sisters vainly hope that all will end well тщетно, напрасно

$\mathrm{V}+\mathrm{V}$

IncepFunc: begin to hope: begin to When your life has been shattered it is difficult to begin to hope again начинать 
ContFunc: continue to hope: continue to We continue to hope for the successful rescue of Secretary Jesse Robredo по-прежнему

Prepositions: for We had a wonderful time at the hotel and that the room was everything we hoped for! на

Phrases: I hope so I'll hope all money back - I think so надеюсь, что это так | I hope not Do you have to work late tonight? - I hope not надеюсь, что этого не будет | to hope against hope We are hoping against hope that some people may have survived вопреки всему | to hope for the best I continue to hope for the best and hope that we can reach an agreement на лучшее, на благоприятный исход | hope and pray We sincerely hope and pray common sense and justice will prevail $\sim$ и молиться | (not) date (to) I scarcely dare hope the plan would succeed (не) сметь $\sim$ secretly hope $I$ have been secretly hopping that some kind of a compromise might be found втайне / в душе

Usage: В отрицательных предложениях, где глагол to hope выражает суждения, отрицание используется с глаголом в придаточном предложении: I hope very much that we will never meet again. We hope he doesn't find it out. B значении «надеяться на что-либо» вместо глагола to hope употребляется глагол to expect: I expect to get necessary information in the near future. We didn't expect to get such a good job.

As the example shows the entrance of the dictionary is made with the use of the functional principle of collocational interpretation of the word. It includes the synthesis of several ways of combinatory exemplification (lexical functions, interpretation, lexical sets, phrases and sentences) of the headword.

The present stage of linguistic development is characterized by the increasing number of researches of collocations as an object of description. It is confirmed by continuous improvement of combinatory dictionaries [32-34, 36]. At the heart of this situation there are following provisions of Combinatory Lexicography.

Firstly, international relations in different fields of knowledge demand the high-qualified experts who speak fluently foreign languages. It is known that lexical and phraseological collocability on the basis of which collocations are formed represent the most difficult area of studying a foreign language particularly taking into account its productive skills. In this case collocability must be described by means of the anthropocentric approach to learning language. Following the principle of language inhesion to the person's consciousness the learner's dictionary is considered as the object of linguistic, lexicographic and methodical description. The basis of collocational interpretation in the learner's dictionary is the principle of methodological validity. Linguistics describing language regarding to this approach is called pedagogically focused.
Secondly, it is necessary to compile orthological collocations dictionaries for experts in philological areas. Their purpose is to record the most completed list of the headwords collocates according to the language standard. These dictionaries belong to the anthropocentric area and are intended only for native speakers or to be more exact for experts in one of the fields of speech activity (writers, journalists, editors, etc.).

Thirdly, of great importance is collocability in the aspect of contrastive study in two or several language systems. It is extremely necessary to compile bilingual and bilingualized dictionaries that interpret contrastive collocations. Their users are professional translators.

Fourthly, for the purely linguistic purpose it is necessary to describe the language without its inhesion to consciousness of the person. In this regard the linguocentric approach to language can be singled out in which the language presents the reality recorded in existed texts. Respectively linguistics describing language on the basis of the linguocentric approach is called systemocentric. Dictionaries of the thesaurus type for linguists should refer to this area. They have to reflect possible connections between words whenever being recorded in printing and colloquial sources.

Fifthly, entries in printing dictionaries in their current representation cannot satisfy completely the user's needs because of the lack of contextual examples. The solution of this problem is becoming possible due to the development of new computer technologies. First of all it belongs to such perspective and intensively developing area as Computational Combinatory Lexicography. Universities and publishing houses are making extensively databanks and corpora which are being replenished and updated. Such modern resources are a valuable potential for investigation of collocation for scientific, educational, informational and other purposes.

These provisions determine the basic blocks of Combinatory Lexicography. Learner's Combinatory Lexicography, Orhtological (Monolingual) and Bilingual Lexicography belong to the anthropocentric area. System Combinatory Lexicography belongs to the linguocentric area. Computational Combinatory Lexicography is on a joint of anthropocentric and linguocentric linguistics and therefore its belonging to one of these spheres should be established in the course of compiling electronic combinatory dictionary.

These results allow us to conclude that the current situation of society favors the emergence and further development of Combinatory Lexicography as an important part of Linguistics that studies collocations.

\section{Conclusion}

We now bring the results of the previous sections together. The separation of Combinatory Linguistics is confirmed both in theoretical and applied consideration. It is a complex systemic formation including theoretical sections - 
Combinatory Lexicology and Combinatory Semasiology and an applied section or Combinatory Lexicography. Each section has the problems to solve, the purpose of study, conceptual and terminological base and probative scientific theory that determines the foundations of Combinatory Linguistics as a separate branch and testifies to its importance in the field of theoretical linguistics.

In conclusion it should be noted that the potential of Combinatory Linguistics is extensive and encouraging. Great opportunities lie in the field of Combinatory Phonetics, Morphology and Syntax. In the perspective it is reasonable to select Combinatory Pragmatics which purpose is to describe metaphoric models and interpret illocutionary force as manifestations of pragmatic valence realized by collocations in speech acts. It is necessary to consider perspective researches in the field of Combinatory Lexicology and Semasiology, e. i. the study of collocational nature caused by connotational and cultural specificity of semantics.

Abundant language material provides for the study of syntagmatic aspect of various concepts represented by definite lexemes. The study of combinatory potential of words in contrastive aspect within native and foreign languages is also necessary to recognize innovative and perspective.

As noted in the paper Combinatory Linguistics represents a complex area that includes theoretical and applied sections with perspectives, purposes of research, terminological framework and the theory that justifies the importance of its separation in the structure of theoretical linguistics.

All in all, the idea of Combinatory Linguistics is a universal approach to the research of all levels of language which gives great opportunities for investigating cognitive and communicative peculiarities of human speech.

\section{References}

[1] Bondzio, Wilhelm (1978). Abris der semantischen Valenztheorie als Grundlage der Syntax. 1. Teil. ZPSK, Bd.29, H. 4, 1976; 2. Teil. ZPSK, Bd. 30, H. 3, 1977; 3. Teil.ZPSK, Bd. 31, H.1.

[2] Chomsky, Noam. (1957). Syntactic Structures. The Hague: Mouton.

[3] Erben, Johannes (1960). Abriß der deutschen Grammatik. Berlin.

[4] Harris, Zellig S. (1951). Methods in Structural Linguistics. Chicago: The University of Chicago Press.

[5] Helbig, Gerhard. (1965). Der Begriff der Valenz als Mittel der strukturellen Sprachbeschreibung und des Fremdsprachenunterrichts // Deutsch als Fremdsprache. H. 1. S. $10-23$.

[6] Katz, Jerrold J., Fodor Jerry A. (1963). The Structure of a Semantic Theory. Language. Vol. 39. № 2. Pp. $170-210$.

[7] Востоков, Александр Х. (1817). Опыт о русском стихосложении. Россия. Санкт-Петербург.

[8] Крушевский, Николай В. (1883). Очерк науки о языке. Изв. и учен. зап. Имп. Казан. ун-та. Казань, Т.XIX.
Январь-Апрель.

[9] Добиаш, Антон В. (1897). Опыт симасиологии частей речи и их форм на почве греческого языка. Прага : тип. др. Э. Грегра.

[10] Добиаш, Антон В. (1882). Синтаксис Аполлония Дискола. Киев.

[11] Saussure, Ferdinand de (1916). Cours de linguistique générale. Ed. Charles Bally and Albert Sechehaye. Paris: Payot, (Based on students' lecture notes, 1907-1911).

[12] Tesnière, Lucien (1953). Eléments de syntaxe structural. Librairie C. Klincksieck, 1959.

[13] Firth, John Rupert (1957). Papers in Linguistics 1934-1951 London: Oxford University Press.

[14] Hjelmslev, Louis (1961). Prolegomena to a Theory of Language. Baltimore: Indiana University Publications in Anthropology and Linguistics (IJAL Memoir, 7) (2nd OD (slightly rev.): Madison: University of Wisconsin Press.

[15] Bloomfield, Leonard (1933). Language. London. George Allen \& Unwin LTD.

[16] Apresyan, Yuriy D. (1974). Lexical Semantics: Synonymic Means of the Language. Moscow, Nauka.

[17] Котелова, Надежда 3. (1975). Значение слова и его сочетаемость. Л. : Наука.

[18] Тер-Минасова, Светлана Г. (1980). Синтагматика речи: онтология и эвристика: (Общая и английская синтагматика составных номинативных групп). М. : Изд-во МГУ.

[19] Амосова, Наталья Н. (1968). Английская контекстология. Л. : Изд-во ЛГУ.

[20] Золотова, Галина А. (1971). Очерк функционального синтаксиса русского языка // Автореферат диссертации на соискание ученой степени доктора филологических наук. М. : АН СССР, Институт русского языка.

[21] Мельчук, Игорь А. (1974). Опыт лингвистических моделей «Смысл $\Leftrightarrow$ Текст». М. : Наука.

[22] Гак, Владимир Г. (1972). К проблеме семантической синтагматики. Проблемы структурной лингвистики 1971 IV. Вопросы грамматики и семантики. М. : АН СССР, Институт русского языка.

[23] Копыленко, Моисей М., Попова Зинаида Д. (1978). Очерки по общей фразеологии. Воронеж : Изд-во ВГУ.

[24] Кубрякова, Е. С. (2002). Когнитивная лингвистика и проблемы композиционной семантики в сфере словообразования. Известия РАН. Серия литературы и языка. 1. С. $13-24$.

[25] Рахилина, Екатерина В. (2000). Когнитивный анализ предметных имён: от сочетаемости к семантике. М. : Азбуковник.

[26] Плеханов, Александр Е. (1999). Лексическая сочетаемость слов в идиоэтническом аспекте. Автореферат диссертации канд. филол. наук. Самара.

[27] Выготский, Лев С. (1996). Мысль и слово. М. : Лабиринт. 
[28] Лурия, Александр Р. (1975). Основные проблемы нейролингвистики. М. : Изд-во МГУ.

[29] Лурия, Александр Р. (1998). .Язык и сознание. М. : Изд-во МГУ.

[30] Леонтьев, Алексей А. (1969)..Язык, речь, речевая деятельность. М.: Просвещение.

[31] Vlavatskaya Marina V. (2013) Theoretical Fundamentals of Combinatory Linguistics: Lexicological and Lexicological Aspects. Thesis of the Doctor in Philology. Russia, Novosibirsk: State Technical University. Department of Foreign Languages. Department of the Humanities.

[32] LTP Dictionary of Selected Collocations (1998). LTP. Ed. by J. Hill, M. ewis. LTP.
[33] Macmillan Collocations Dictionary (2010). Macmillan.

[34] Oxford Collocations Dictionary (2002). Oxford University Press.

[35] Dobrovol'skij, D.O. (2005) Semantic Motivation of Lexical Functions and its Limits (The Combinatorial Profile of the Russian Degree Modifier črezvyčajno). East West Encounter: Second international conference on Meaning-Text Theory. Ed. by Ju. D. Apresjan and L.L. Iomdin. - Moscow: Slavic Culture Languages Publishing House. Pp. 110 - 121.

[36] Benson, Morton, Benson, Evelyn, etc. (1990). The BBI Combinatory Dictionary of English. M. : Русский язык. 